\title{
Competence of teaching grammar communicatively as a part of linguadidactic competence of future English teachers
}

\author{
Makhkamova Komila \\ Samarkand State University \\ kamila.makhkamova@mail.ru
}

Abstract

Objective: To analyze the effectiveness of competence of teaching grammar communicatively as a part of linguadidactic competence of English teachers the teaching-learning process.

Methods: A pre-experimental study was conducted. It involved 36 university students from five faculties (6 males and 30 famales) between 18 and 22 years old. A questionnaire validated by experts was created to evaluate competence of teaching grammar communicatively as a part of linguadidactic competence of English teachers.

Results: The results report the significant effectiveness of competence of teaching grammar communicatively as a part of linguadidactic competence of English teachers and advantages teaching grammar communicatively.

Conclusions: was useful to use competence of teaching grammar communicatively as a part of linguadidactic competence of English teachers during teaching English as a foreign language as they are related to real life, as teacher tries to encourage students using authentic materials.

Keywords

Communicative language teaching, lingudidactic competence, competence of teaching grammar communicativly; Communicative; Teaching grammar;

Article Received: 18 October 2020, Revised: 3 November 2020, Accepted: 24 December 2020

\section{Introduction}

Higher Education inUzbekistan has experienced expectant moments. Policies and state directives are looking for an increase in the academic quality to make professional work appropriate to the needs of the country. So that the needs of improving demand of learning foreign languages, especially English is also actual nowadays.

Language teaching is a process. It requires teachers' deep realizing the aspects of language teaching and learning. "...teaching is not simply the application of knowledge and of learned skills...(it is) a much more complex cognitivelydriven process affected by the classroom context, the teacher's general and specific instructional" (Richards, J. C., 2008). This citation makes us to think and deeply understand that we have to pay attention on communicative language teaching approach during teaching English as a foreign language. Moreover, when learning a foreign language, such as English, the teacher's existence in the classroom is even more paramount. Learning foreign languages does not result in the same learning experience of the learners. We know that some learners are born with a flair for languages and find language learning as an enjoyable and successful experience; we also clearly understand that others have difficulties trying to make sense of the language, hence a daunting, threatening and frustrating experience for them. The teacher has the responsibility to ensure that language learning takes place. "Learning can only take place in an appropriate environment and it's commonplace that it is the teacher's job to create a favourable learning environment." (Corder, 1990). So we realize that we are creaters an effective environment for learning foreign languages and the CLT is bright approach to achieve this goal. We easily can use CLT during teaching grammar. But during teaching grammar, one of the biggest challenges teachers face is how to make their students achieve conceptual understanding.

Literature Review (Times New Roman, bold, 12)

Grammar teaching across the globe can therefore be considered traditional in either a pedagogical or 
a linguistic sense, or in both respects, even when a country's educational ideology promotes something different (Fearn and Farnan, 2007; Horn, 2003; Lefstein, 2009; Van Rijt et al., 2018; Watson, 2015). One of the main reasons why grammar education contends with a traditional image relates to teacher knowledge. Research shows that language teachers generally lack sufficient metalinguistic knowledge (e.g. Alderson \& Hudson, 2013; Sangster, Anderson, \& O’Hara, 2013) and experience low self-confidence, even anxiety, in the linguistic domain (Giovanelli, 2015). Teaching grammar based on real insights rather than rules ofthumb presents teachers with severe challenges, both when teaching grammar in isolation and when teaching grammar effectively in the context of writing (cf. Myhill, Jones, \& Watson, 2013). Teaching grammar based on parsing isolated sentences puts less cognitive strain on teachers, who mostly lack the knowledge and confidence to teach grammar insightfully. Moreover, research into teacher beliefs has revealed that teachers generally tend to adopt teaching styles that match the content and pedagogies which they have experienced themselves as learners (e.g. Phipps \& Borg, 2017; Watson, 2015).

Up to now, much of research has focused on the relative effectiveness of explicit and implicit grammar instruction. In most of the studies (Akakura, 2009; Andrews, 2007; DeKeyser, 1995; Doughty, 1991; Ellis, 1993; Ellis, Loewen \& Erlam, 2006; Han, 2012; Hunter, 1996; MorganShort et al., 2010; Norris \& Ortega, 2000; Radwan, 2005; Robinson, 1996; Rosa \& O'Neill, 1999; Scarcella, 1996; Schneider, 1993; VanPatten \& Oikennon, 1996), explicit and implicit instruction were compared with respect to their effectiveness on EFL learners' success in grammar.

"Learners do not learn one thing perfectly, one at a time, but numerous things simultaneously (and imperfectly). The linguistic flowers do not all appear at the same time, nor do they all grow at the same rate. Some even appear to wilt, for a time, before renewing their growth "Nunan, 1998".

Students should develop their own understandings of the grammatical principles of English through inductive learning experiences which encourage them to explore the functioning of grammar in context.Over time, students should encounter target language items in an increasingly diverse and complex range of linguistic and experiential environments (Nunan, 1998).

\section{Methodology (Times New Roman, bold, 12)}

For this study tasks pre and post tests have been administered to 36 students, two groups which were consisted of 18 students in each, from the preparatory classes of Samarkand State University. They were chosen at random and were all intermediate level students between the ages of 18 and 22. So, we had chosen the group where we used the grammar communicatively in case to make clearer, effective, real, and more interesting the given theme to the students what we had chosen for experiment. In order to understand the effect of competence of teaching grammar communicatively during teaching. And another teacher taught them not paying attention on CLT, communication, even any extra materials while teaching the theme. The theme for the students of the University was "Prepositions of locations" 3. First of all we paid attention on the theme and tried to teach the theme according the usage of these prepositions in the real situations of life. As the aim of the getting good result in teaching of target theme we tried to use the some realias by bringing objects, showing pictures, cards: using containers, markers, paper and pens during teaching English as a foreign language. In order to give information about the prepositions of locations we chose the video, picture, and realias which described the target theme.at the lesson were used two activities which supplemented each other in case to teach prepositions of location communicatively (Table 1.(a,b), Table 2.(a, b)) 
Table 1a

\section{ACTIVITY ONE: ARRANGE THE OBJECTS}

- 1. Once students are comfortable with the prepositions, inform them that they will play a game to test their understanding. Divide the students into two or three teams and give each team a name.

- 2. Show students the two containers you have prepared and say, "This container has all of the names of the objects that are on the table. This container has all of the prepositions you have just learned. Two members of your team will come up to the front of the class together. One person will choose a preposition card and the other will choose two object cards. Then you will work together to arrange the objects to illustrate the preposition and use it in a sentence about the objects. Your team will earn one point for correct arrangement of the objects and one point for your sentence."

- 3. Choose two students to come up to the front of the class and model the process of choosing the cards, arranging the objects, and forming a sentence. Provide guidance as needed and give students time to ask questions about the game.

- 4. Once students are ready, play the game and keep score. The activity can either be timed, or played until all students have had a chance to participate. The team with the most points at the end of the activity wins!

Table $1 b$

\section{PREPARATION}

\section{OBJECTS}
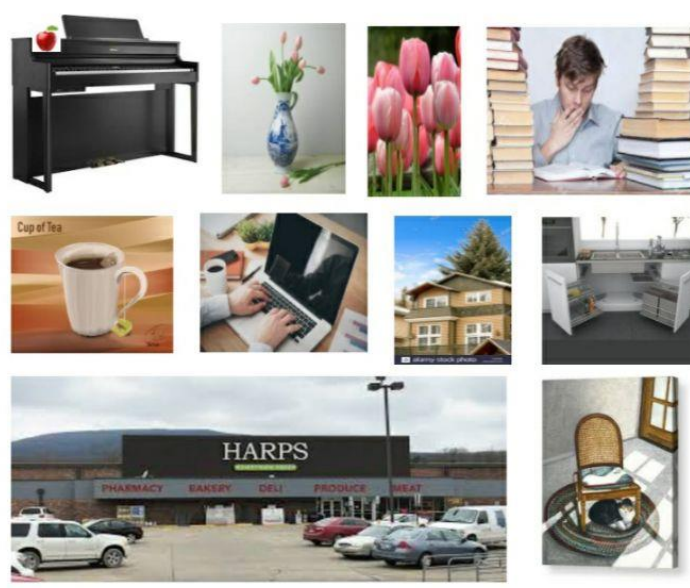

PREPOSITIONS

$\circ \mathrm{On}$

○ In

- Beside

- Next to

- Under

- Below or above

o between 
It was also effective method to learn English as a foreign language. Moreover, it was excellent chance to increase their speaking, writing and listening abilities on the English language also. It was also productive way of motivating learners to learn foreign languages what they would be able to use in the real situations of life and was excellent opportunity to think critically during writing.

Table 2a

\section{ACTIVITY TWO: DESCRIBE THE SCENE}

- 1. Have the class form pairs or small groups of 3-4 students.

- 2. Rearrange the objects on the table if you have just played the game in Activity 1. On the board, list the prepositions you want students to use.

- 3. Explain that you will set a timer for five minutes. During the five minutes, groups of students should try to write as many sentences as they can about the objects on the table using each of the prepositions on the list. They must use all of the prepositions once before repeating any.

- 4. After the timer has stopped, groups will exchange papers and check each other's sentences. Students will check for correct use of prepositions and verify that the sentences correctly describe the location of the objects on the table. Groups earn one point for each correct sentence.

- 5. Once the sentences have been checked and points have been added up, the group with the most points wins. You can ask groups to share some of their sentences to provide further review. To repeat this activity, rearrange the objects on the table and have students work in different groups.

Table $2 b$

\section{WRITE AS MANY SENTENCES AS YOU CAN}

\section{Objects}

\section{Prepositions}
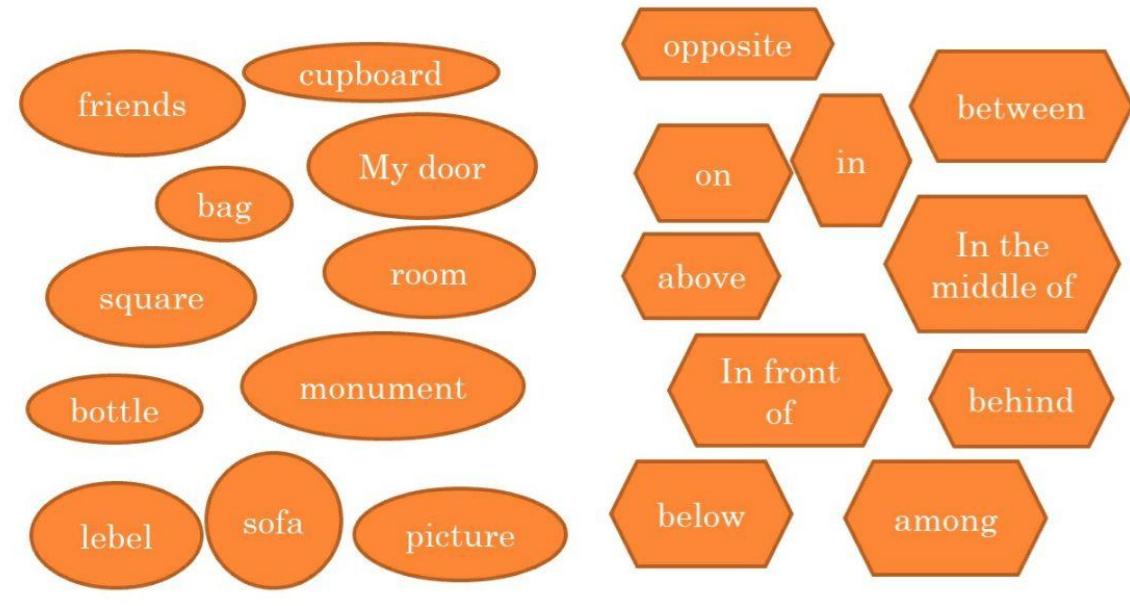


\section{Data Analysis and Results}

First, the pretest was administered to all participants. Then, eighteen of those students were practiced with the teacher who competence of teaching grammar communicatively during the experiment. And the second teacher experimented without any CLT and not using any professional competence during teaching the target theme. Subsequently all the students were given exactly the same test as the post test. The tasks and the tests had been carried out in the exam which is used to after each topic. The post test was applied experienced group which were practiced with the teacher who used competently competence of teaching grammar communicatively also used the realias by showing video and pictures, moreover by bringing realias to the classroom in case to to the students just after they had completed the tasks. This, of course, increases the reliability of the test results since it was held when the effects of the tasks were still fresh.

In order to compare the results of the same test was given to both groups; we tested them with the same tests. But received results of two groups differed. The group what the teacher taught them not paying attention on any CLT and not using any professional competence during teaching the target theme obtained progress in 14 only, but the

make the lesson clearer and more interesting the given theme to the students what we had chosen for experiment acquired 17.

\begin{tabular}{|c|c|c|c|}
\hline Groups & Number of students & Mean & $\begin{array}{c}\text { Assimilation } \\
\text { percentage }\end{array}$ \\
\hline Experienced group & 18 & 17 & 94 \\
\hline $\begin{array}{c}\text { Non-experienced } \\
\text { group }\end{array}$ & 18 & 14 & 78 \\
\hline
\end{tabular}

As a result students learned the topic better and besides understanding given professional competent teacher who taught them grammar communicatively become much more active, friendlier, easy going, confident, motivated and communicable, critical thinker, flexible, reliable,happy rather than the second group. Moreover, the next lesson students from experimented group answered to all questions of the teacher using prepositions of locations in their own real life situations and were more confident during speaking.

In the result the lesson itself was student centered and it gave an opportunity for students to use the language to communicate, to express their ideas, speaking English as much as possible to have purpose for communicating, having desire to communicate

\section{Discussions}

The aim of the study was to analyze the effectiveness of an competence of teaching grammar communicatively intervention to support the management of the teaching-learning process. The results indicate the presence of a significant impact in the framework that supports the management of the teaching-learning process in university students.

An experienced group was taught by the teacher who used the grammar communicatively in case to make the target theme clearer, effective, real and more interesting to the students. In order to understand the effect of competence of teaching grammar communicatively during teaching obtained progress in 17 from 18 is clear that the experience made students more successful rather than another group where teacher did not payed attention on any professional competence of teaching grammar communicatiuvely and did not used any realias acquired 14 only from 18 . 
According to given result of testing two groups, where the teachers taught the target topic in different methodology and by different qualified teachers. We realize that the using realias with teacher's professional competence og teaching grammar communicatively is significant not less than having knowledge and ability of giving rules about the topic and the language what they want to teach. So we think paying attention on the using communicative grammar teaching competence during teaching the student who will learn the topic with teacher's professional competence of EFL teachers during teaching the target language and it's grammar much more fruitful rather than not paying attention on them.

Firsly, the English lessons become more, interesting, organized, created, consulted, evaluated, motivated and positive with friendly atmosphere. So the students also will be motivated to continue cognize and learn the language and grammar communicatively. Students become more organized, confident, open-minded, active, creative and communicable.

Secondly, students have different types of opportunities to approach to constantly developing their communicative abilities, have many speaking and writing tasks and cognize Content more important than form during learning target foreign language.

Thirdly, it gives to try to increase teachers competency of teaching grammar communicatively as a part of linguadidactic competence of future English teachers and make lesson more effective than before as the method of teaching is much more interesting for learners as the target topic will be tougt according CLT.

Fourthly, and not less important point that is much more consciously magnificent that the using realias, realistic use of language in context and professional competency of EFL teachers wll effect advantageously and motivate learners to learn some foreign languages.

Fifthly, future English teachers will gain professional competence of teaching grammar communicatively as a part of linguadidactic competence at their early learning being teacher.

\section{Conclusion}

In order to obtain better result it was useful to use competence of teaching grammar communicatively as a part of linguadidactic competence of English teachers during teaching English as a foreign language. Moreover, practicing and using professional competence of teaching grammar communicatively as a part of linguadidactic competence is using perspective technic during teaching and carry up students' involvement and motivation mainly because these competences are related to real life, as teacher tries to encourage students using authentic materials. To conclude, it is seen that the results of the experience show that students' success increases when teacher uses her or his professional competence, when she or he tries to be a perspective teacher using CLT in order to teach grammar and thus leads learners to further communication. It is clear that competent teachers are at least as important as teaching subject. This study suggests that students' success rises when teachers are professionally competent in classes and also in their professional life.

\section{Acknowledgement}

I acknowledge Samarkand State University and the $1^{\text {st }}$ year students of Russion Philology Faculty, Foreign language and literature direction for helping me to make my experiment. And I deeply appreciate my scientific superviser Bakiyeva Gulandom for her advices and for giving me scientific directions on my research work.

\section{References}

[1] Alderson, J., \& Hudson, R. (2013). The metalinguistic knowledge of undergraduate students of English language or linguistics. Language Awareness, 22(4), 320-337. http://dx.doi.org/10.1080/09658416.2012. 722644 
[2] Al-Kalbani, N. R. (2004). Omani English teachers' and students' perceptions of the role of grammar instruction in EFL teaching and learning. Unpublished master's thesis, Sultan Qaboos University, Muscat

[3] Borg, S., \& Burns, A. (2008). Integrating grammar in adult TESOL classrooms. Applied Linguistics, 29(3), 456-482.

[4] Burgess, J., \& Etherington, S. (2002). Focus on grammatical form: explicit or implicit? System, 30(4), 433-458

[5] Corder, P. (1990). Talking shop: Pit Corder on language teaching and applied linguistics. In Rossner, R. And Bolitho, R. Currents of change in English language teaching. (pp 110-117). Oxford: Oxford University Press

[6] Fearn, L., \& Farnan, N. (2007). When is a Verb Using Functional Grammar to Teach Writing. Journal of Basic Writing, 26(1), $1-26$.

[7] Giovanelli, M. (2015). Becoming an English Language teacher: Linguistic knowledge, anxieties and the shifting sense of identity. Language and Education, 29(5), 416-429. http://dx.doi.org/10.1080/09500782.2015. 1031677

[8] Horn, A. (2003). English grammar in schools. In P. Collins, \& M. Amberber (Eds.), Proceedings of the 2002 conference of the Australian Linguistics Society (p. $\mathrm{xx}$ )

[9] Lefstein, A. (2009). Rhetorical grammar and the grammar of schooling: Teaching 'powerful verbs' in the English national literacy strategy. Linguistics and Education, (20), 378-400. http://dx.doi.org/10.1016/j.linged.2009.04. 002

[10] Makhkamova K.T. (2020). English teachers' professional competence by using realias in teaching. Journal of critical review,

206-208

http://www.jcreview.com/?mno=97205

[11] Myhill, D., Jones, S., \& Watson, A. (2013). Grammar matters: How teachers' grammatical knowledge impacts on the teaching of writing. Teaching and Teacher Education, 36, 77-91. http://dx.doi.org/10.1016/j.tate.2013.07.00 5

[12] Nunan, David (1998) "Teaching Grammar in Context”. In: ELT Journal, 52/2, ntext.pdf

[13] Phipps, S., \& Borg, S.(2017). Exploring tensions between teachers' grammar teaching beliefs and practices. System, 37, 380-390.

[14] Richards, J. C. (2008). Second language teaching education today. RELC Journal, 39, 158-168

[15] Sangster, P., Anderson, C., \& O'Hara, P. (2013). Perceived and actual levels of knowledge about language amongst primary and secondary student teachers: Do they know what they think they know? Language Awareness, 22(4), 293-319. http:// dx.doi.org/10.1080/09658416.2012.72264 3

[16] Thu, T. H. (2009). Teachers' Perceptions about Grammar Teaching. Retrieved 5th of December, 2009 from http://files.eric.ed.gov/fulltext/ED507399. pdf

[17] Van Rijt, J., De Swart, P., \& Coppen, P.A. (2018). Linguistic concepts in L1 grammar education: A systematic literature review. Research Papers in Education, $1-28$. http://dx.doi.org/10.1080/02671522.2018. 1493742

[18] Wang, B. (1999). English grammar instruction in Taiwan: Student and teacher attitudes. Unpublished doctoral dissertation, Pennsylvania State University, Pennsylvania. 
[19] Watson, A. (2015). Conceptualisations of grammar teaching: L1 English teachers' beliefs about teaching grammar for writing. Language Awareness, 24(1), 114.

http://dx.doi.org/10.1080/09658416.2013. 828736 